Anais da Academia Brasileira de Ciências (2019) 91(3): e20181104

(Annals of the Brazilian Academy of Sciences)

Printed version ISSN 0001-3765 / Online version ISSN 1678-2690

http://dx.doi.org/10.1590/0001-3765201920181104

www.scielo.br/aabc | www.fb.com/aabcjournal

\title{
Description of a second known Liotyphlops caissara specimen (Serpentes: Anomalepididae)
}

\author{
ARTHUR D. ABEGG ${ }^{1,2}$, WEVERTON S. AZEVEDO ${ }^{1}$, FRANCISCO L. FRANCO ${ }^{1}$ and MARCELO R. DUARTE ${ }^{1}$ \\ ${ }^{1}$ Laboratório Especial de Coleções Zoológicas, Instituto Butantan, Avenida Vital Brasil, 1500, 05503-900 São Paulo, SP, Brazil \\ ${ }^{2}$ Universidade de São Paulo/USP, Instituto de Biociências/IB, Rua do Matão, 14, 05508-090 São Paulo, SP, Brazil
}

Manuscript received on October 19, 2018; accepted for publication on June 17, 2019

\begin{abstract}
How to cite: ABEGG AD, AZEVEDO WS, FRANCO FL AND DUARTE MR. 2019. Description of a second known Liotyphlops caissara specimen (Serpentes: Anomalepididae). An Acad Bras Cienc 91: e20181104. DOI 10.1590/00013765201920181104.
\end{abstract}

\begin{abstract}
We recorded a second specimen of the poorly known insular blind snake Liotyphlops caissara. This new specimen expands the morphological variation of the number of dorsal scales in the genus Liotyphlops to 296 (vs. 304 in L. wilderi) and, considering the fact that the holotype of this species was destroyed, the present specimen represents the only available $L$. caissara individual in zoological collections. Also, this new record constitutes the first out of type locality and expands the distribution of the species in about $40 \mathrm{~km}$ to the northeastern. According to IUCN criteria (B1a, b [iii]), we suggest that L. caissara be included in the "Endangered" category, since it occurs in only two insular locations and exhibits an occurrence extension of $<5,000 \mathrm{~km}^{2}$ (about $355 \mathrm{~km}^{2}$ ).
\end{abstract}

Key words: Atlantic rainforest, geographic distribution, morphological variation, southeastern Brazil.

\section{INTRODUCTION}

The genus Liotyphlops Peters, 1860 comprises small snakes, widely distributed in the Neotropical region (Dixon and Kofron 1984, Freire et al. 2007, Centeno et al. 2010). It is the most speciesrich genus among Anomalepididae snakes, with 12 currently recognized species (Santos and Reis 2018). According to Dixon and Kofron (1984) they are externally characterized by a large rostral scale in contact with the frontal, preventing contact between the prefrontals; a slender and elongated body, completely covered with 18 to 28 rows of smooth and cycloid scales; number of dorsals along the body ranging from 304 to 589; eye spot visible or not. As noted by these authors, a great

Correspondence to: Arthur Diesel Abegg

E-mail: arthur_abegg@hotmail.com

ORCid: https://orcid.org/0000-0002-4264-8943 morphological variation is observed within this genus, and even within same populations, making the taxonomy of this group problematic and challenging. To make matters worse, their secretive habits and diminutive size lead to relatively low encounter rates in nature, and some species are known from only a few specimens, hindering a more accurate understanding of their quantitative and qualitative characters (Dixon and Kofron 1984, Centeno et al. 2010). Recently, a number of herpetological fieldwork studies carried out on the coastal islands of Southeastern Brazil have provided opportunities for documenting rare species, as well as registering new insular distributions. In this study, we report a second specimen of the poorly known insular blind snake Liotyphlops caissara Centeno, Sawaya \& Germano, 2010.

L. caissara is known from only one individual, from Ilha de São Sebastião, in the municipality of 
Ilhabela, in the state of São Paulo, Southeastern Brazil. The L. caissara holotype is a unique insular Anomalepididae from the Southeastern Brazilian coast, which was, unfortunately, lost in a fire in May 2010 at the "Coleção Herpetológica Alphonse Richard Hoge" of Instituto Butantan (IBSP), São Paulo, SP, Brazil (see Franco 2012). A second known L. caissara specimen from Anchieta Island is recorded and described herein.

\section{MATERIALS AND METHODS}

This second specimen (Figure 1) was revealed during a survey of Anchieta Island State Park $(-23.5500,-45.0666$, DATUM WGS 84) herpetofauna (approximately $30 \mathrm{~km}$ northeastern of the type locality). The Anchieta Island State Park (Figure 2) comprises the entire Anchieta Island ( $828 \mathrm{ha}$ ), being part of the Atlantic Forest biome and housing Dense Ombrophilous Forest and Restinga remnants (Veloso et al. 1991). The specimen was found dead by Paulo Cicchi in a pitfall trap on October $28^{\text {th }}, 2008(-23.55,-45.06$; at sea level), and deposited as IBSP 89927.

All measurements, as well as photographs, were taken in the lab. Sex was determined by a longitudinal incision at the base of the tail to check for the presence/absence of hemipenes. Measurements (in mm), terminology for the head scalation and scale counts follows Dixon and Kofron (1984) and Centeno et al. (2010).

\section{RESULTS}

The specimen is a young male. In general, is similar in scale characters to the holotype, and presents the same colour pattern, with a dorsal dark brown uniform colour (Figure 1d), and continuous pale cream colour throughout the venter (Figure 1e). More specifically, the measures are as follows (holotype IBSP 76774, in brackets): scales contacting the posterior edge of the prefrontal, three (three); scale contacting the posterior edge of the nasal, between the second supralabial and prefrontal, one (one); scales in the first vertical row of dorsals, four (four); supralabials, three (three); infralabials, three (three); dorsal scale rows, 2322-20 (22-20-20); dorsals in a longitudinal row, 296 (326); ventrals in a longitudinal row, 274 (308); subcaudals, 14 (10); head length, $2.02 \mathrm{~mm}$ $(4.46 \mathrm{~mm})$; head width, $2.48 \mathrm{~mm}(2.78 \mathrm{~mm})$; snoutvent length, $133 \mathrm{~mm}$ (191 mm); tail length, $5.5 \mathrm{~mm}$ (4 mm). A comparison to published characters from other species belonging to the Liotyphlops genus is given in Table I.

\section{DISCUSSION}

This encounter of a second L. caissara specimen is remarkable, as the species seems to be rare, since herpetofauna inventories lasting one year were carried out in both areas where the presence of this snake was recorded, using different snake-collecting methodologies, with no further records of any additional specimens (Cicchi et al. 2009, Centeno et al. 2010). Additionally, this new specimen expands the morphological variation of the number of dorsal scales in the Liotyphlops genus, at 296 (vs. 304 in L. wilderi, Dixon and Kofron 1984) and, considering the fact that the holotype of this species was destroyed (F.L. Franco, unpublished data) the present specimen is particularly important, as it represents the only available $L$. caissara individual in zoological collections.

We show that $L$. caissara is not restricted to its type locality, contrary to other insular snake species along the Brazilian Atlantic coast (Marques et al. 2002, Barbo et al. 2012, 2016). Both islands where $L$. caissara was found are located close to the mainland $(<3 \mathrm{~km})$, where sea depth is relatively low (ca. 4-5 m) (Martin et al. 1986). This may mean a recent isolation for this species from continental populations, possibly during the medium Holocene (ca. 3,800-4,000 ya), when sea levels were ca. 4-6 m lower than currently observed (Massad et al. 1996). This hypothesis is 
TABLE I

Morphological Liotyphlops characters from literature data and the present study.

\begin{tabular}{|c|c|c|c|c|c|c|c|c|c|}
\hline Species/Count & PEP & PEN & FVRD & SL & IL & ASR & MSR & PSR & DSR \\
\hline L. albirostris ${ }^{1,3}$ & 3 & 1 & 4 & 4 & 4 & $23-26$ & $20-22$ & $20-23$ & $370-520$ \\
\hline L. anops ${ }^{1,3}$ & 4 & 2 & 6 & 4 & 4 & $24-28$ & 24 & $22-24$ & $547-589$ \\
\hline L. argaleus ${ }^{1}$ & 4 & 1 & 5 & 4 & 4 & $26-28$ & $22-24$ & 22 & $482-533$ \\
\hline L. beui ${ }^{1,3}$ & 3 & 2 & 5 & 4 & 4 & $22-26$ & $20-24$ & 20 & $384-464$ \\
\hline L. caissara, & 3 & 1 & 4 & 3 & 3 & $22-23$ & $20-22$ & 20 & $296-326$ \\
\hline L. haadi ${ }^{5}$ & 3 & 1 & 4 & 4 & 3 & 20 & $19-20$ & $18-20$ & $333-384$ \\
\hline L. schubarti ${ }^{1,3}$ & 3 & 2 & 5 & 4 & 4 & 22 & $20-21$ & 20 & $372-387$ \\
\hline L. sousai ${ }^{5}$ & 4 & 2 & 6 & 4 & 3 & 24 & 22 & 20 & 439 \\
\hline L. taylori ${ }^{5}$ & 3 & 2 & 5 & 4 & 2 & 22 & 20 & 20 & 455 \\
\hline L. ternetzii ${ }^{1,3}$ & 3 & 2 & 5 & 4 & 4 & $23-26$ & $22-24$ & 22 & $463-510$ \\
\hline L. trefauti $i^{2,4}$ & 4 & 1 & 5 & $3-4$ & $3-4$ & 22 & 22 & 22 & $520-548$ \\
\hline L. wilderi $^{1,3}$ & 3 & 1 & 4 & 4 & 4 & $22-24$ & $20-22$ & 20 & $304-358$ \\
\hline
\end{tabular}

Sources: ${ }^{1}$ Dixon and Kofron (1984); ${ }^{2}$ Freire et al. (2007); ${ }^{3}$ Centeno et al. (2010); ${ }^{4}$ Gonçalves et al. (2016), ${ }^{5}$ Santos and Reis (2018), and ${ }^{6}$ this study. PEP = number of scales contacting the posterior edge of prefrontal; PEN = number of scales contacting the posterior edge of the nasal between the second supralabial and prefrontal; FVRD = number of scales in the first vertical row of dorsals; SL = number of supralabial scales; IL = number of infralabial scales; ASR = number of anterior scale rows around the body; MSR = number of scale rows around the midbody; PSR = number of posterior scale rows around body; DSR = number of dorsal scale rows.

reinforced by the absence of L. caissara specimens in islands farther from the continent (ca. 35-40 km), such as Alcatrazes, Queimada Grande and Vitória, where several herpetological expeditions have already been conducted to study Bothrops species (Barbo et al. 2016) and whose process of insularization is estimated between 12,000-10,000 (Martin et al. 1986).

However, the presence of L. caissara on two islands remains unclear. There are at least two possible scenarios to explain this question. In the first scenario (1) the populations of both islands would have arisen independently from the rising sea level and suffered similar selective pressures. As a result, populations would converge morphologically to the point of becoming similar and difficult to discriminate (especially with only one individual from each island). This scenario is observed for some island species of Bothrops (Barbo et al. 2012, 2016). In this context, populations of $L$. caissara could represent distinct species, potentially diagnosable through the number of dorsal and ventral scales. The collection of additional individuals from both islands would help elucidate
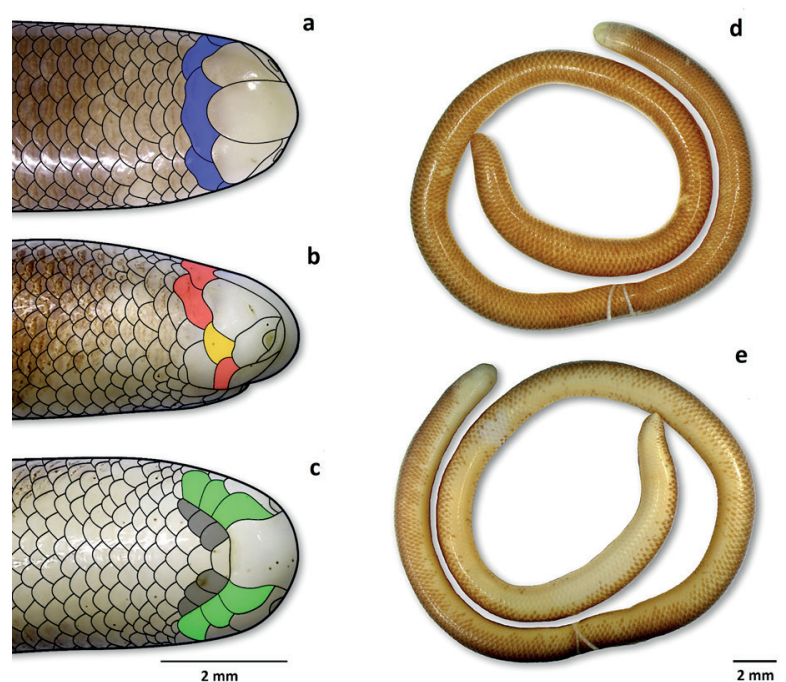

Figure 1 - Dorsal (a), lateral (b), and ventral (c) views of the head, and dorsal (d) and ventral (e) view of entire body of the second known Liotyphlops caissara (IBSP 89927) specimen, from Anchieta Island, São Paulo, southeastern Brazil. Blue scales (Figure 1a) = PEP; Red and orange scales (b) = FVRD; Orange scale $(\mathbf{b})=$ PEN; Green and grey scales $(\mathbf{c})=$ SL and IL, respectively.

whether this difference in the number of scales is a fixed character state or represents morphological extremes within the same taxon. The alternative 


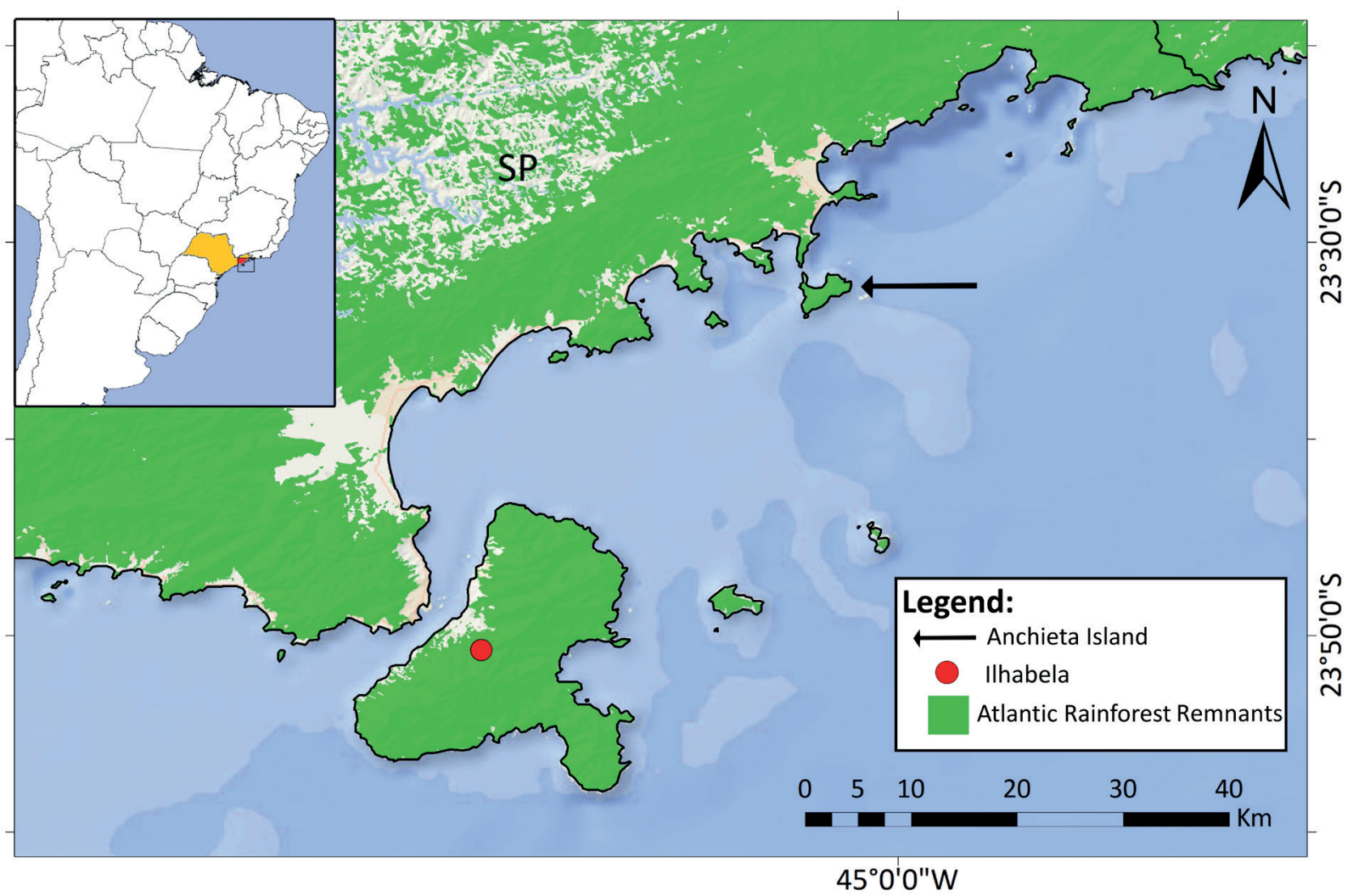

Figure 2 - Geographic distribution of Liotyphlops caissara. The circle indicates the type locality, while the arrow represents the locality of the new specimen (IBSP 89927), found at Anchieta Island (-23.55, -45.06) São Paulo (SP), southeastern Brazil.

scenario (2) refers to dispersion by water. More specifically, the disjoint distribution of L. caissara could be the result of a long-distance dispersal event, through flotsam from the founding island population. This scenario has been speculated to explain the dispersion between continents and islands in different groups of reptiles, including scolecophidian snakes (Vidal et al. 2010). At this point, we are unable to speculate about the polarity of this hypothetical dispersal events. However, studies on the biogeography of Brazilian Atlantic coast islands and the time of divergence of their respective reptile faunas are in progress and could contribute in the elucidation of these questions (F. Grazziotin, unpublished data).

As a number of authors have noted (reviewed by Diamond 1984), the risk of extinction decreases with increasing habitat size and population density (Dodd
1987). Even so, according to IUCN criteria (IUCN 2017) we suggest that $L$. caissara be included in the "Endangered" category, under the following criteria: B1a, b [iii]. This state of conservation is justifiable because $L$. caissara exhibits the occurrence extension of about $255 \mathrm{~km}^{2}\left(<5,000 \mathrm{~km}^{2}, \mathrm{~B} 1\right)$; is known from only two localities $(<5, \mathrm{~B} 1 \mathrm{a})$; and the habitat quality on both islands showed continuous decline in the recent past (Centeno 2008, Cicchi et al. 2009) (B1a, b [iii]).

\section{ACKNOWLEDGMENTS}

The authors would like to thank Rogério Bertani (Instituto Butantan - São Paulo (IBSP)) for his help with the L. caissara head photographs, Marco Sena (Instituto de Biociências da Universidade de São Paulo (IBUSP)) and Valdir Germano (Instituto Butantan - São Paulo (IBSP)) for help in identifying 
and pholidosis data collection; Henrique Caldeira Costa (Universidade Federal de Viçosa (UFV)) and one anonymous reviewer for their review and comments that improved the manuscript; Paulo Passos and Manoela W. Cardoso (Museu Nacional - Rio de Janeiro (MNRJ)), Giuseppe Puorto (Instituto Butantan - São Paulo (IBSP)) and Hussam Zaher and Aline S. Benetti (Museu de Zoologia da Universidade de São Paulo (MZUSP)) for information and allowing access to specimens under their care.

\section{AUTHOR CONTRIBUTIONS}

ADA and WSA: Contribution to concept and design of the study, data collection and manuscript preparation.

FLF and MRD: Contribution to concept and design of the study and critical review of the manuscript.

\section{REFERENCES}

BARBO FE, GASPARINI JL, ALMEIDA AP, ZAHER H, GRAZZIOTIN FG, GUSMÃO RB, FERRARINI JMG AND SAWAYA RJ. 2016. Another new and threatened species of lancehead genus Bothrops (Serpentes, Viperidae) from Ilha dos Franceses, Southeastern Brazil. Zootaxa 4097: 511-529.

BARBO FE, GRAZZIOTIN FG, SAZIMA I, MARTINS M AND SAWAYA RJ. 2012. A new and threatened species of lancehead from Southeastern Brazil. Herpetologica 68: 418-429.

CENTENO FC. 2008. Diversidade e uso do ambiente pelos anfíbios e répteis da ilha de São Sebastião, Ilhabela, SP Dissertação de Mestrado, Universidade de São Paulo. (Unpublished data).

CENTENO FC, SAWAYA RJ AND GERMANO VJ. 2010. A new species of Liotyphlops (Serpentes: Anomalepididae) from the Atlantic Coastal Forest in southeastern Brazil. Herpetologica 66: 86-91.

CICCHI PJP, SERAFIM H, SENA MA, CENTENO FC AND JIM J. 2009. Herpetofauna em uma área de Floresta Atlântica na Ilha Anchieta, município de Ubatuba, sudeste do Brasil. Biota Neotrop 9: 201-212.

DIAMOND JM. 1984. "Normal" extinctions of isolated populations. In: Nitecki MH (Eds), Extinctions. The University of Chicago Press, Chicago, USA, p. 191-246.
DIXON JR AND KOFRON CP. 1984. The Central and South American anomalepid snakes of the genus Liotyphlops. Amphib-Reptil 4: 214-264.

DODD CK. 1987. Status, conservation, and management. In: Seigel RA, Collins JT and Novak SS (Eds), Snakes Ecology and Evolutionary Biology. McGraw Hill, New York, USA, p. 478-514

FRANCO FL. 2012. A Coleção Herpetológica do Instituto Butantan: da sua origem ao incêndio ocorrido em 15 de maio de 2010. Herpetologia Brasileira 1: 22-31.

FREIRE EMX, CARAMASCHI U AND ARGÔLO AJS. 2007. A new species of Liotyphlops (Serpentes: Anomalepididae) from the Atlantic Rain Forest of Northeastern Brazil. Zootaxa 1393: 19-26.

GONÇALVES U, GALDINO JYA, BRITO PS, TORQUATO S AND PALMEIRA CNS. 2016. Liotyphlops trefauti Freire, Caramaschi and Argôlo, 2007 (Squamata: Anomalepididae): Distribution extension and geographic distribution map. Bol Mus Biol Mello Leitão 38: 325-330.

IUCN - INTERNATIONAL UNION FOR CONSERVATION OF NATURE. 2017. Guidelines for using the IUCN Red List categories and criteria. Version 13. Prepared by the Standards and Petitions Subcommittee. Available at: http:// cmsdocs.s3.amazonaws.com/RedListGuidelines.pdf.

MARQUES OAV, MARTINS M AND SAZIMA I. 2002. A new insular species of pitviper from Brazil, with comments on evolutionary biology and conservation of the Bothrops jararaca group. Herpetologica 58: 303-312.

MARTIN L, MÖRNER NA, FLEXOR JM AND SUGUIO K. 1986. Fundamentos e reconstrução de antigos níveis marinhos do Quaternário. Bol Inst Cienc Biol 4: 1-161.

MASSAD F, SUGUIO K AND PEREZ FS. 1996. Propriedade geotécnica de sedimentos argilosos como evidência de variações do nível relativo do mar em Santos. In: $8^{\circ}$ Congresso Brasileiro de Geologia de Engenharia. Rio de Janeiro (Eds), Anais da Associação Brasileira de Geologia de Engenharia e Ambiental, p. 163-176.

SANTOS FJM AND REIS RE. 2018. Two New Blind Snake Species of the Genus Liotyphlops (Serpentes: Anomalepididae), from Central and South Brazil. Copeia 106: 507-514.

VELOSO HP, RANGEL-FILHO ALR AND LIMA JCA. 1991. Classificação da vegetação brasileira, adaptada a um sistema universal. Instituto Brasileiro de Geografia e Estatística. Rio de Janeiro: IBGE, 124 p.

VIDAL N, MARIN J, MORINI M, DONNELLAN S, BRANCH WR, THOMAS R AND HEDGES SB. 2010. Blindsnake evolutionary tree reveals long history on Gondwana. Biol Lett 6: 558-561. 